\title{
Analysis of Russia's Modern Economy Structure
}

\author{
Valeriy Smirnov ${ }^{1, *}$, Dmitry Sokolov ${ }^{1}$, Mikhail Grigoriev ${ }^{1}$, Olga Romanova ${ }^{1}$, Mikhail Alexandrov ${ }^{1}$ \\ and Denis Osipov ${ }^{1}$ \\ ${ }^{1}$ Chuvash State University named after I.N. Ulyanova, Moskovsky prospekt, 15, 428015, Cheboksary, \\ Russia \\ *Corresponding author
}

Keywords: Integration, System Approach, Stable Clusters, Structure, Functionality.

Abstract: Subject of the study is the structure of Russian economy. The aim of the work is to determine parameters of the modern Russian economy structure functionality. The article substantiates the need for application of theoretical provisions and methodological approaches of structural functionalism to the economic policy of Russia to solve the problem of ensuring stable economic growth by increasing the functionality of the structure of the economy. Analysis of Russia's modern economy structure functionality revealed two stable clusters: government spending on final consumption and consumer price index. These clusters show the targets for implementation of model of ensuring the functionality of the structure of modern Russian economy. Estimation of limit values can be carried out using Cobb-Douglas formula in which the main factors are the consumer price index in accordance with the Central Bank's policy on inflation targeting, and government spending on final consumption (government spending on public procurements).

\section{Introduction}

Growing inefficiency of fixed assets and growth of excess savings of population during the last years of the USSR, as well as their subsequent depreciation in 1992-1994, contributed to revision of the existing relationships in the economic system of Russia. This need was exacerbated during the prolonged recession of 2015-2016 reinforcing the chronic problems of the Russian economy - the low ability to self-generate economic growth (low multiplier of output in the economy as a whole, the level of inter-sectoral interactions and the length of value chains decreased compared to the early 1980s, unchanged institutional shell).

In order to improve the structure it is necessary to abandon the dogmas of market fundamentalists and move to consideration of economy as an eternally living system not stabilizing at the equilibrium point but passing through a structural crisis and updating its technological and institutional structure, entering a new growth trajectory [1].

Among the many options for solving the problem of entering a new trajectory of sustainable economic growth there is distinguished a method based on the theory of structural functionalism. 


\section{Literature Review}

The founder of structural functionalism is the American sociologist-theorist Talcott Parsons who in his researches relied on the classical concepts of French philosopher Isidore Marie Auguste Francois Xavier Comte, the English philosopher and sociologist Herbert Spencer, the French sociologist and philosopher David Emile Durkheim, the British social anthropologist of Polish origin Bronislav Kasper Malinowski that allowed him to fully disclose the theory of structural functionalism as an idea of "social order" [2,3]. The source of social order was the creative force of the natural order which inevitably institutionalizes a man [4].

Principles of structural functionalism inspire development of a rich variety of theoretical foundations including the theory of systems, some areas of Marxist analysis and neo-functional approaches in the social sciences [5]. Methodological provisions of structural functionalism are fully realized in the theory of social networks [6].

Methodological provisions of the study of structural functionalism are widely used in science [5] both at the level of strategy formation [7] and at the level of economic policy implementation [8].

In the conditions of falling rates of world trade, strengthening of global competition, active change of a technological way of economy of Russia the priority is given to the strategy of structural modernization [9, 10] providing transformations of economy on the evolutionary principles of neo-Darwinism and revaluation of macro-sociological theories [11].

\section{Method}

Statistical, cluster and nonparametric analysis, autocorrelation and cross-correlation methods are used to analyze the functionality of the structure of the modern Russian economy.

Statistical analysis as a method of collecting, studying and presenting large amounts of data will reveal the main regularities and trends of a certain phenomenon [12]. Cluster analysis is a multidimensional statistical procedure for collecting data containing information about a sample of objects and ordering the objects of research into relatively homogeneous groups [13].

Neural network analysis is associated with the construction of neural networks that recognize patterns and learn to better identify them during the process. Nonparametric analysis in terms of statistics over data is defined as a function over samples, it is independent from the parameter the interpretation of which does not depend on the population corresponding to any parameterized distributions.

Autocorrelation and cross-correlation methods are used to assess the significance of structure parts that provide the best functionality of the modern economy.

\section{Result \& Analysis}

To analyze the functionality of the modern Russian economy structure we will use the statistical data from the Organization for Economic Co-operation and Development (OECD). The analysis algorithm includes the following sequential steps:

1) assessment of growth rates of economic indicators;

2) cluster analysis of growth rates of economic indicators and determination of significant clusters;

3) nonparametric analysis of growth rates of economic indicators and determination of indicators with the rejected hypothesis;

4) identification of stable clusters (combination of results of the assessment of growth rates, cluster and nonparametric analysis of growth rates);

5) determination of optimal coordination of structural elements of stable clusters of the Russian economy using autocorrelation and cross-correlation methods. 
Growth rates of economic indicators. As a result of assessment of the growth rates of 80 indicators of the Russian economy for 2009-2020, presented in the OECD the main set of indicators is as follows: current account balance; gross fixed capital formation; Gross Domestic Product (GDP) per capita; GDP; government expenditures on final consumption; country's share of trade in world trade; imports of goods and services; Consumer Price Index (CPI); CPI-based competitiveness indicator; final domestic expenditures; personal expenditures on final consumption; private final consumption expenditures; exports of goods and services.

Cluster analysis. Results of cluster analysis of the samples are indicative of the economy of modern Russia (calculated in "SPSS Statistics" according to the OECD.Stat. https://stats.oecd.org. Accessed: 2019/09/18. "Hierarchical cluster analysis. The average distance between clusters, the square of the Euclidean distance") revealed seventeen narrow groups. The most numerous of them are based on final domestic expenditures and private final consumption expenditures, government final consumption expenditures, GDP (deflator), CPI.

Significant (frequency of occurrence) indicators of the Russian economy growth rate: GDP per capita; GDP (nominal value); GDP (market prices); government expenditures on final consumption (nominal value, approach to GDP); government expenditures on final consumption (volume); imports of goods and services; imports of goods and services (nominal value); CPI; trade in goods and services; export market of goods and services. Priority group of economic indicators: GDP, government expenditures on final consumption and CPI. This priority characterizes the shift of the structural functionalism of the Russian economy towards the government (public expenditures on final consumption) and the Central Bank of Russia (CPI).

Non-parametric analysis. As a result of nonparametric analysis there have been revealed the rejected null hypotheses of economic indicators growth rates. Among the rejected null hypotheses there is actual GDP per capita.

Combination of the results of growth rate assessment, cluster and non-parametric analysis of the Russian economy indicators growth rates revealed two bases for stable clusters - government spending on final consumption and CPI.

As a result of autocorrelation and cross-correlation analysis the boundary conditions for the choice of structural elements of the Russian economy have been revealed:

1) government spending on final consumption - imports of goods and services, GDP, GDP per capita, gross fixed capital accumulation;

2) CPI - government spending on final consumption.

So, the model of ensuring of the modern Russian economy structure functionality includes government spending on final consumption and CPI as well as the range of problems being solved by the existing relationships - imports of goods and services, GDP, gross fixed capital accumulation. The limit capabilities of interaction between the corresponding structural elements can be displayed using the modified Cobb-Douglas function

$$
F S=A \cdot|G F C E|^{\alpha} \cdot C P I^{\beta},
$$

$F S$ - Functionality of Structure; $A$ - arithmetic mean of growth rates of imports of goods and services, GDP, gross fixed capital accumulation; $|G F C E|$ - Government final consumption expenditures (module of arithmetic mean of growth rates of nominal value, volume, percentage growth, deflator); CPI - Consumer Price Index); $\alpha$ - elasticity coefficient of government expenditures on final consumption; $\beta$ - elasticity coefficient CPI.

Results of modeling of the modern Russian economy functionality structure (Figure 1 ) revealed stable dynamics at $\alpha=0.25, \beta=0.75$, unstable at $\alpha=\beta=0.5$. 


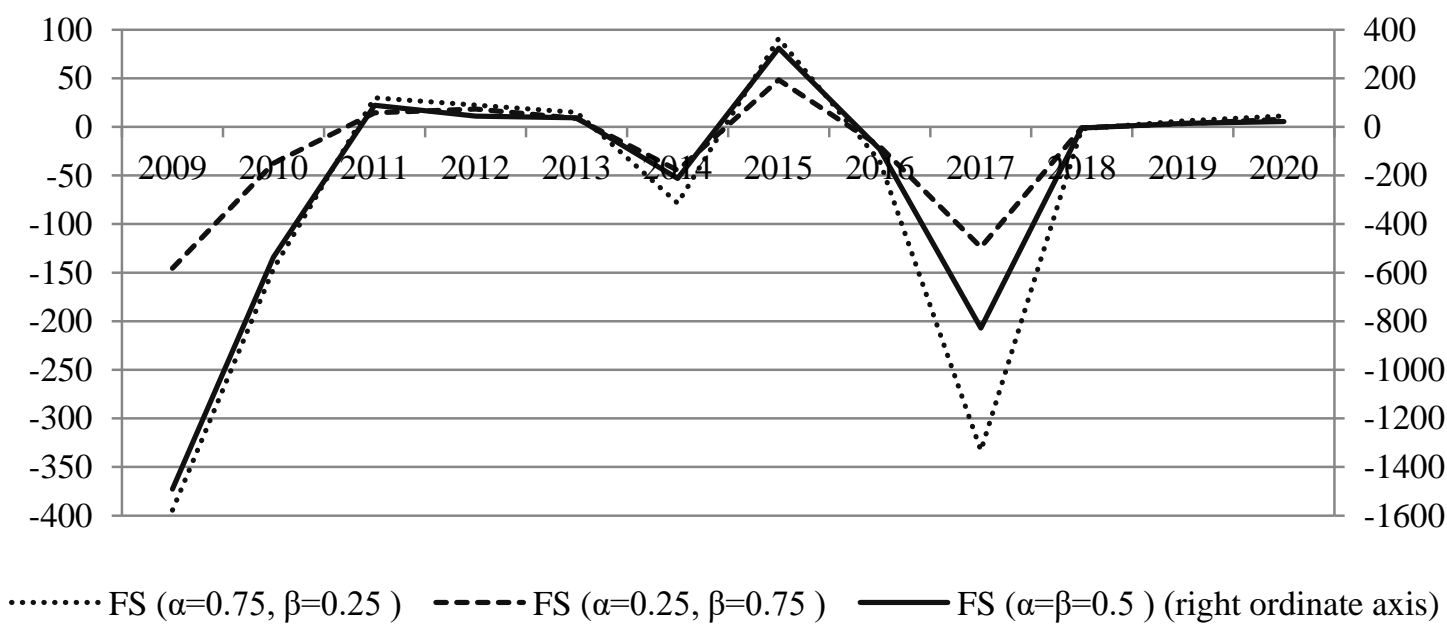

Note: Cobb - Douglas formula.

Source: calculated in SPSS Statistics according to the Organization for Economic Cooperation and Development. OECD.Stat. URL: https://stats.oecd.org. Accessed: 18.09.2019.

Figure 1.Modeling the Structural Functionality of the Modern Russian Economy.

Thus, in order to stabilize the processes in the modern Russian economy it is necessary to focus on CPI, and for the purpose of development it is necessary to maintain parity between CPI and government spending on final consumption.

\section{Discussion of Results}

Thus, management of the Russian economy is linked to the policy of the Central Bank on inflation targeting which allows the Russian government to regulate the pace of its growth and development through public spending on final consumption most of which are public procurements.

In this model of provision of modern Russian economy structure functionality the main role is played by the Ministry of Finance which not only regulates matters of budgetary policy allocating money to various programs and projects but of economic development of the country in general.

According to the results of the study the export-oriented enterprises producing competitive products using imported equipment, raw materials and basic materials become a priority for the development of Russian economy.

The basis of the economic policy of modern Russia should be the functional integration of parts of the Russian economy structure formed under specific conditions and implemented on the principles of social networks theory. The proposed algorithm for analysis of the Russian economy structure functionality should become a key method of functional integration, and the use of cluster and nonparametric analysis, autocorrelation and cross-correlation should become the main tool for formation of stable clusters that contribute to sustainable economic growth and development.

The results of the study should be used for implementation of the main provisions of the Federal law “On strategic planning in the Russian Federation”.

\section{Conclusion}

In the context of decrease in the global trade rates growth, increased global competition, changing technological structure and transformation of the world order the solution of the problem of sustained 
economic growth lies in active economic policy of authorities aimed at improvement of functionality of the economy structure. The basis of economic policy should be the theory of structural functionalism - functional integration of differentiated parts of a certain structure implemented in the theory of social networks.

As a result of implementation of algorithm for analysis of the Russian economy structure functionality there have been identified: dynamically stable indicators (current account balance, gross accumulation, GDP, government spending on final consumption, etc.); priority group of economic indicators (GDP, government spending on final consumption and CPI); boundary conditions (government spending on final consumption); significant relationships (government spending on final consumption with CPI, imports of goods and services, GDP, gross fixed capital accumulation).

The impact of CPI on government spending on final consumption shows the priority of the Russian government to regulate the economy based on the policy of inflation targeting. Within the framework of the policy for inflation targeting and reduction of the federal budget expenditures the public procurements become a defining parameter of Russian economy development.

\section{References}

[1] V. Smirnov, V. Semenov, E. Kadyshev, A. Zakharova, I. Guschin, T. Kravchenko, M. Yaklashkin, O. Filippova, Effective Public Administration of the Russian Economy. Proceedings of the International Conference on Communicative Strategies of Information Society (CSIS 2018). Advances in Social Science, Education and Humanities Research, 2019, 289: 64-68. https://doi.org/10.2991/csis-18.2019.13

[2] B.R. Green, E.A. Johns, The structural-functional approach to social analysis. An Introduction to Sociology, 1966: 102-119. https://doi.org/10.1016/B978-0-08-012154-3.50008-9

[3] N. Fontes, J. Shelby, B. O'connor, A Structural-Functional Model of the Message-Attitude-Behavior Relationship. Message-Attitude-Behavior Relationship. 1980: 303-317. https://doi.org/10.1016/B978-0-12-199760-1.50015-7

[4] A.J. Hughes, D.M. Lambert, Functionalism, structuralism, and "Ways of seeing". Journal of Theoretical Biology, 1984, 111 (4): 787-800. https://doi.org/10.1016/S0022-5193 (84) 80267-2

[5] J.E. Castro, Functionalism (Including Structural Functionalism). International Encyclopedia of Human Geography. 2009: 277-282. https://doi.org/10.1016/B978-008044910-4.00692-1

[6] E. McCord, Structural-functionalism and the network idea: towards an integrated methodology. Social Networks. 1980, 2(4): 371-383. https://doi.org/10.1016/0378-8733(80)90004-0

[7] R. Münch, Functionalism, History of. International Encyclopedia of the Social \& Behavioral Sciences (Second Edition), 2015: 536-542. https://doi.org/10.1016/B978-0-08-097086-8.03183-4

[8] V.V. Smirnov, D.G. Osipov, A.A. Babaeva, E.V. Grigorieva, E.F. Perfilova, Parity of innovation and digital economy in the Russian management system. Modern Management Trends and the Digital Economy: from Regional Development to Global Economic Growth (MTDE 2019). Advances in Economics, Business and Management Research, 2019: 22-27. https://doi.org/10.2991/mtde-19.2019.5

[9] S. Malle, Economic modernisation and diversification in Russia. Constraints and challenges. Journal of Eurasian Studies, 2013, 4(1): 78-99. https://doi.org/10.1016/j.euras.2012.07.004

[10] A. Lavopa, A. Szirmai, Structural modernisation and development traps. An empirical approach. 
World Development, 2018, 112: 59-73. https://doi.org/10.1016/j.worlddev.2018.07.005

[11] P. Nolte, Modernization and Modernity in History. International Encyclopedia of the Social \& $\begin{array}{llll}\text { Behavioral Sciences } & \text { (Second } & \text { Edition), } & \text { 2015: }\end{array}$ https://doi.org/10.1016/B978-0-08-097086-8.62007-X

[12] J. Lazar, J.H. Feng, H. Hochheiser, Chapter 4: Statistical analysis. Research Methods in Human $\begin{array}{lllll}\text { Computer Interaction } & \text { (Second }\end{array}$ https://doi.org/10.1016/B978-0-12-805390-4.00004-2

[13] A. Adolfsson, M. Ackerman, N.C. Brownstein, To cluster, or not to cluster: An analysis of clusterability methods. Pattern Recognition, 2019, 88: 13-26. https://doi.org/10.1016/j.patcog.2018.10.026 